\title{
Superblocks Practice in the Southern, Brasilia and Sha Tin, Hong Kong
}

\author{
Junhao CHEN, City University of Hong Kong, China \\ Jiaxuan ZHU, The University of Hong Kong, China
}

\begin{abstract}
This paper studies the blocks in the south of Brasilia under the theory of Modern City by Le Corbusier, and compares it with the blocks in the new town of Sha Tin. The process of the practice of livable communities in the 20th century is discussed in this paper, especially the block modes. The two cases were built in similar forms and under similar construction concept. Through literature analysis, comparative analysis and empirical analysis, the number of public service facilities, residential building scale and other information is counted to compare. The conclusion is drawn that the Modern City of Le Corbusier has many shortcomings, such as overemphasis on urban functional zoning, inadequate urban scale, inability to attract a large number of people to live in, and limited utilization of service facilities. The original intention for community construction in Sha Tin public housing estates is to solve the problem of dense urban population and deteriorating living environment. Years of construction have formed a perfect service supporting system to meet the living needs of a large number of people, and play a very important role in boosting the economic development of Hong Kong New Territories. The communities in future will be more livable, more diverse and more resilient.
\end{abstract}

\section{Keywords}

Modern City, Superblock, Public housing

\section{Introduction}

Modern city is one of the most important urban types in the 20th century. It was born under the largescale industrial revolution, with population centralizing and migration growing. Le Corbusier believed that the function of the city should be placed in the first place, while people's practical requirements and psychological need were often missed. In this essay, the author does a comparative study on the southern (Asa Sul) of Brasilia and Shatin New Town, Hong Kong by means of literature and survey. Brasilia is a good example of a modern city, but the grand scale of the planning lacks humanism. On a similar urban scale, Sha Tin New Town is improved in form and function therefore a modern city's connotation was enhancing. closer to human's care. Le Corbusier's modern city theory was constantly practiced and criticized in the next 100 years. Many architects and planners took inspiration from Corbusier's planning model in the Salon in the Autumn of 1922, and applied certain scenes to their planning. Those scattered scenes around the world are integrated into local countries and nationalities. The significance of this paper is to study the community construction in Brasilia and Hong Kong, and to explore a better and more humanized residential design method. 


\section{Literature Review}

\subsection{Background}

The modernist urban idea originated from Le Corbusier. In the context of the industrial revolution in the 1920s, human society was attracted by mechanical aesthetics. The widespread use of new transport tools, such as cars, trains and planes, has expanded the range of human migration and made it easier to form high-density settlements in cities which has happened to Paris and London. When considering the life, living environment deterioration, water shortages, poor hygiene, shortage of public facilities and so on, regarded as city disease, gradually emerged, Neither a current standard, nor a city-self growth mechanism can adapt to the changes brought by the rapid industrialization.

\subsection{Concept of Modern City}

From the perspective of architects, Le Corbusier took functions and rationality into consideration. Then he proposed a future urban development pattern, modern city, including 4 principles:

1) Traditional cities have become obsolete due to the growth of size and the increasing congestion in the city center. Technical intervention can perfect its gathering function.

2) Increasing density can solve crowding problem in cites.

3) New means of transportation and dimensional transportation system are critical to serve the growing population and improve social efficiency.

4) To improve the environment and appropriate scale between human and constructions is increasing the outdoor vegetation area.

These principles integrated into Athens Charter, proposed by Le Corbusier in CIAM,1933. Athens Charter pointed out that living, working, recreation and circulation were the most basic classification in the city study, imposing a great impact in the future.

\subsection{Criticism for Modern City}

Many scholars have described Brasilia as the failure of modernism, exposing the city's backside to the misery of its marginal slums. They even described Brasilia as a mockery of the values of modernism, which had globally bad implications ${ }^{1}$. In recent years, more and more scholars have evaluated Brasilia's planning from land, urban spatial pattern ${ }^{2}$, crime rate ${ }^{3}$, commuting time ${ }^{4}$, housing ${ }^{5}$ and other aspects. Since the end of the 19th century, modern planning has increasingly emphasized the rationality of communication. But the planning of Sha Tin New Town is in the charge of the government. The public participation in the preparation and implementation process was generally low ${ }^{6}$. The flexible planning of New Town adopted phased planning and design, emphasizing the variability of planning to the complex urban system ${ }^{7}$. On the basis of criticizing rational planning, phased planning focuses on the continuous iteration of planning objectives and methods by relying on existing planning policies and experience ${ }^{8}$.

\section{Practical Project Analysis}

\subsection{The southern, Brasilia}

Brasilia, completed in 1960, was mainly planned and designed by Costa and Niemeyer. Although Le Corbusier was absent in Brasilia's project, the two Brazilian masters fully made modern city come true. To be strict, Brasilia was the only one city, built in city-size in accordance with the modernist urban planning theory. The Pilot Plan guided Brasilia to develop with east-west central axis and north-south arc-shaped 
wings on axis's both sides. It was granted as "Famous City of Human History and Culture" by the United Nations in 1987.

In this section, the author takes the residential area in the southern of Brasilia as the main research object. a rectangular area about $7 \mathrm{~km}$ in length and $1.5 \mathrm{~km}$ in width. A $280 \mathrm{~m} \times 280 \mathrm{~m}$ superblock forms a basic community, of which there are 124 super blocks for the whole of Brasilia. A superblock consists of 6 -storey (with the ground floor elevated) apartment buildings, a primary school and a nursery, and plenty of public space for children to play in. Each superblock will accommodate about 360 units and 1,000 to 2,500 residents. Each of the 4 superblocks forms a neighborhood unit. In this level, neighborhood unit provides a church, a middle school, a movie theater, a club and a community park. A number of low-rise retail stores scatter along the edges of superblocks as well as along the driveways. The spaces between the buildings are heavily planted with grass and trees, making Brasilia's per capita greening rate much higher than most of the world.

Instead of streets and squares, spaces for the public are offered in magnificent buildings such as the Brasilia Cathedral and the National Stadium. On the contrast, the most outdoor open space is highway which means the city is completely oriented by autos. Externally, Brasilia can connect any other cities in Brazil by its developed highway network. Internally, however, the highways cross the residential area, cutting the neighborhood units into islands. Autos speed on roads with no traffic lights, while people braved the danger of crossing the road to reach another block. Compared with the colorful life in Rio de Janeiro and Sao Paulo, the city's public spaces function officially without an enjoyable atmosphere. The citizens have nowhere to receive visitors but at home. In addition, the overly detailed, complex and rigid functional zoning only adds to the inconvenience to citizens. The hotel area only gathers hotels, the shopping mall area only has the shopping malls. Some of relevant service are segregated at opposite ends of the city. In pursuit of the overall aesthetic effect, the architects eliminated most of the visual identity. The order and functional zoning pursued by extreme modernism resulted in a boring, repetitive and indifferent living environment that inevitably damages the mental health of residents.

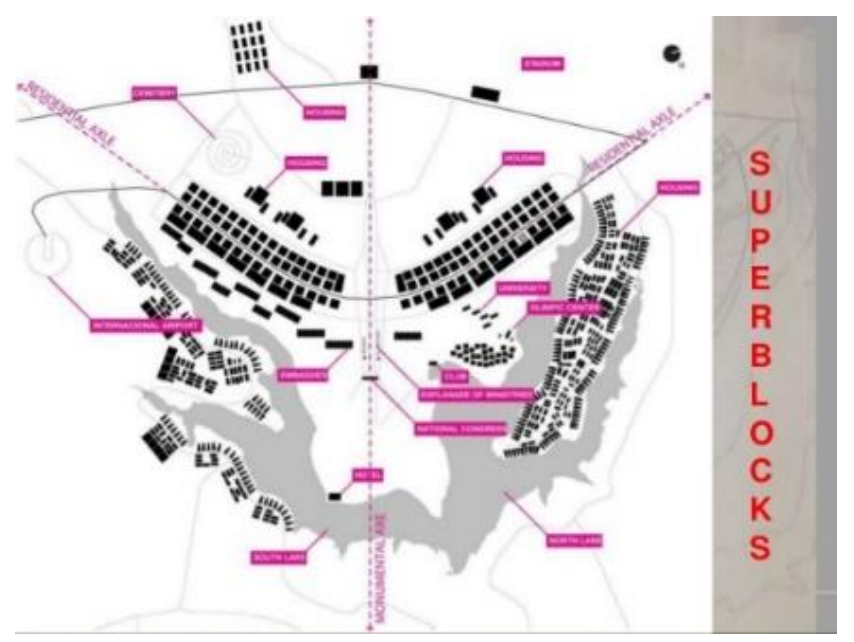

Fig 1.

Source: https://www.slideshare.net/shonabhatnagar/brasilia-town-planning

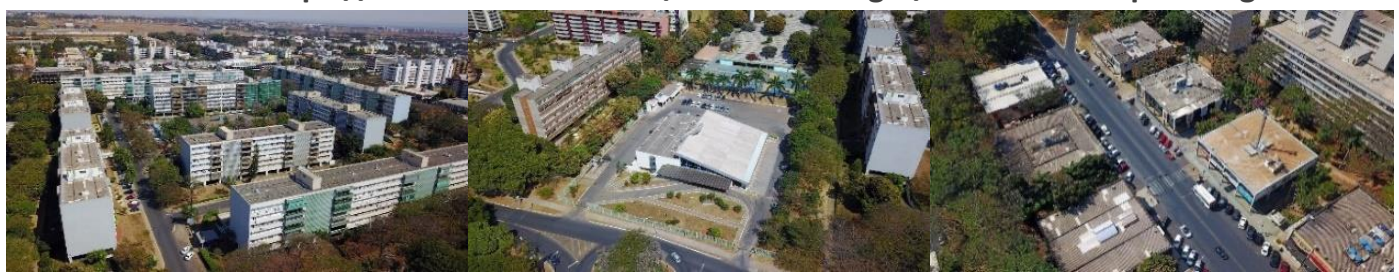


Fig 2. superblock(a), church \& middle school(b), retail building(c)

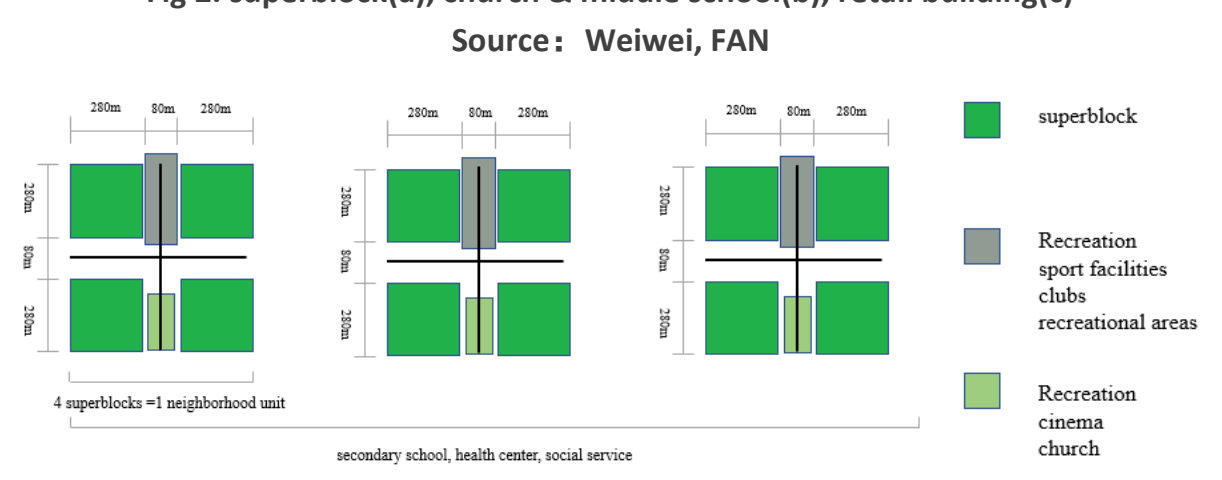

Fig 3. superblock-neighborhood pattern in Brasilia

Source: self-drawing by the author

In 1956, the master plan set the size of the city as 557,000 people, However, the distribution of residential use is administrated by the government. The actual population is less than the planned number. It can be discussed in 2 background groups, the middle class and workers. Most first-generation immigrants were civil servants. Such a similar uniform and monotonous background of residents is quite different from what we recognize before. We usually learn from a city that diverse groups of people are living in. The immigrants created a medical term "Brasilite" to mock the standardization in Brasilia -- the lack of entertainment, communication, consumption and community. More than 60,000 construction workers and 10,000 homeless work on building Brasilia. But they weren't planned as citizens and had no right to own a government apartment in superblock. So, they built their own houses on the west side of two huge wing areas, forming a slum area. Up till now, the situation hasn't changed too much.

In 2017, Brasilia was the third most populous city with 3 million people but 2.4 million people live in 16 satellite cities outside the original urban planning zone. The original intention of the urban planners is to break the isolation caused by wealth differences and mix living of different income groups by designing standardized living communities and livable environments. But the huge imbalances and social problems of Brazil cannot be solved simply by building homogenous and utopian superblocks. The social class and population remain divided.

\subsection{Sha Tin New Town, Hong Kong}

In response to the scarcity of land in Hong Kong, Sir Abercrombie proposed reclaiming land from the sea . In 1950, the project in Shatin Tai Wai started laying the foundation for a new town. Until the 1970s, Sha Tin New Town, as the first generation of new towns, was determined. The new town is a rectangular area of about $7 \mathrm{~km} \times 1 \mathrm{~km}$, similar to the southern of Brasilia. It presents a striped spatial character in development due to transportation. Along Shing Mun River, the town layout circle displays as water axis open space - commercial area - high density residential - industrial - low density residential. Hong Kong government chose low-mobility traffic tools, light train as oriented development. Sha Tin station of the East Rail Line is equipped with a large shopping centre, local bus links and public facilities. Pedestrian bridges were widely used to link each block, which is a good way to keep human flows among superblocks. No worry to cross the busy roads and train tracks. Sub-towns such as Ma On Shan and City One Shatin gradually developed in the 1980s. Until now, it still maintains vitality and it's the largest district about population in Hong Kong. 


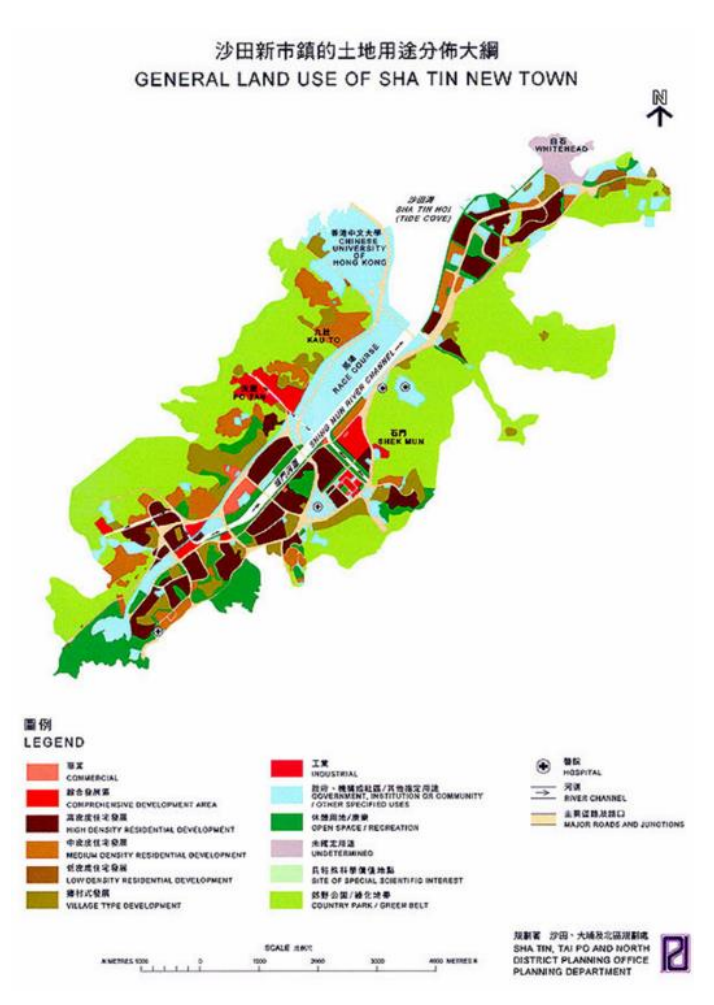

Fig 4.

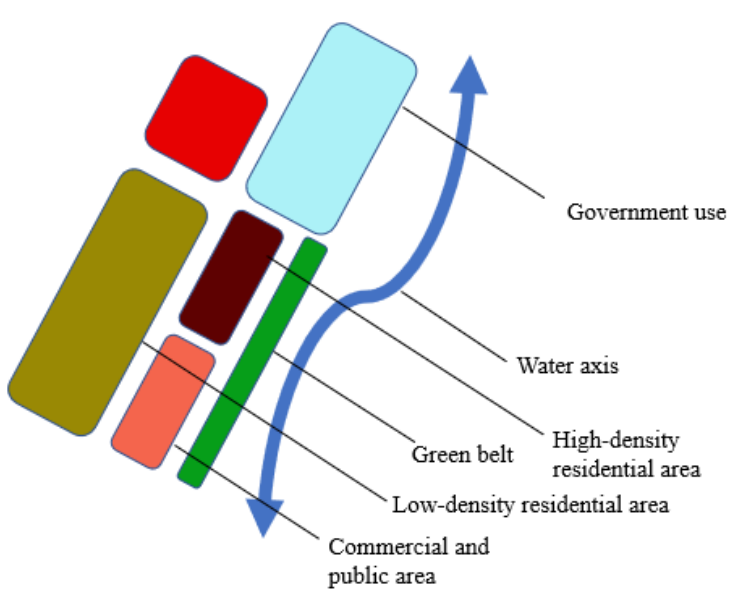

Fig.5

Source: Department of Planning

The concept, superblock, also exists in Hong Kong (Uk Chuen). There are 21 public housing estates, or 21 superblocks, throughout Sha Tin New Town. Taking Lek Yuen Estate as example, it is the first public housing Estate in Sha Tin, opened in 1975. There are seven buildings in block, among which the lowest building has 8 floors while the highest one has 22 floors. The superblock can accommodate 3,200 residential units and 8,300 people. From the number of residents and building height, we can see these buildings are closer to Corbusier's tower. Even if people don't go out of the block, they can find food business area, the youth activity center, the clinic and other convenient living facilities.

For the nearby areas, Sha Tin Town Centre for shopping convenience locates in south-west, as well as accessible to the railway station, linking traditional city center of Hong Kong with here. The open space along Shing Men River has been developed into recreation use which respects the living rights of lowincome residents and enables them a high- quality living environment. It is also not so far for early residents to work in the Fo Tan industrial area. The living circle covers each zoning area within $500 \mathrm{~m}-1 \mathrm{~km}$.

After the second world war, millions of refugees rushed in Hong Kong. They make their living in low-labor industries. This laid the foundation for light industry and accumulated social wealth in Hong Kong. What's more, a series of social movement in 1960s force the colonial government to reflect the policy. Therefore, MacLehose's Home Ownership Scheme came out in 1970. It is a kind of social welfare planning in Hong Kong, also affected by the welfare policy in Britain. Tan Zheng believed that Sha New Town adopted the typical form of Cumbernauld. The Hong Kong British government emphasized the social housing function in new towns, ensuring the residents to work and to live in new towns. Such policies and urban planning compensated the workers and their families by reducing the cost of housing, but encouraged them did more consumption . Later in 1990s, the welfare space changed to consumption space. That means the younger generation, growing up in Uk Chuen (superblock) the welfare space $g$ In New Town, the ratio of public housing to private property developed by Hong Kong's property developers is usually 6:4. The public housing population accounts for $60 \%$ of the total population. 

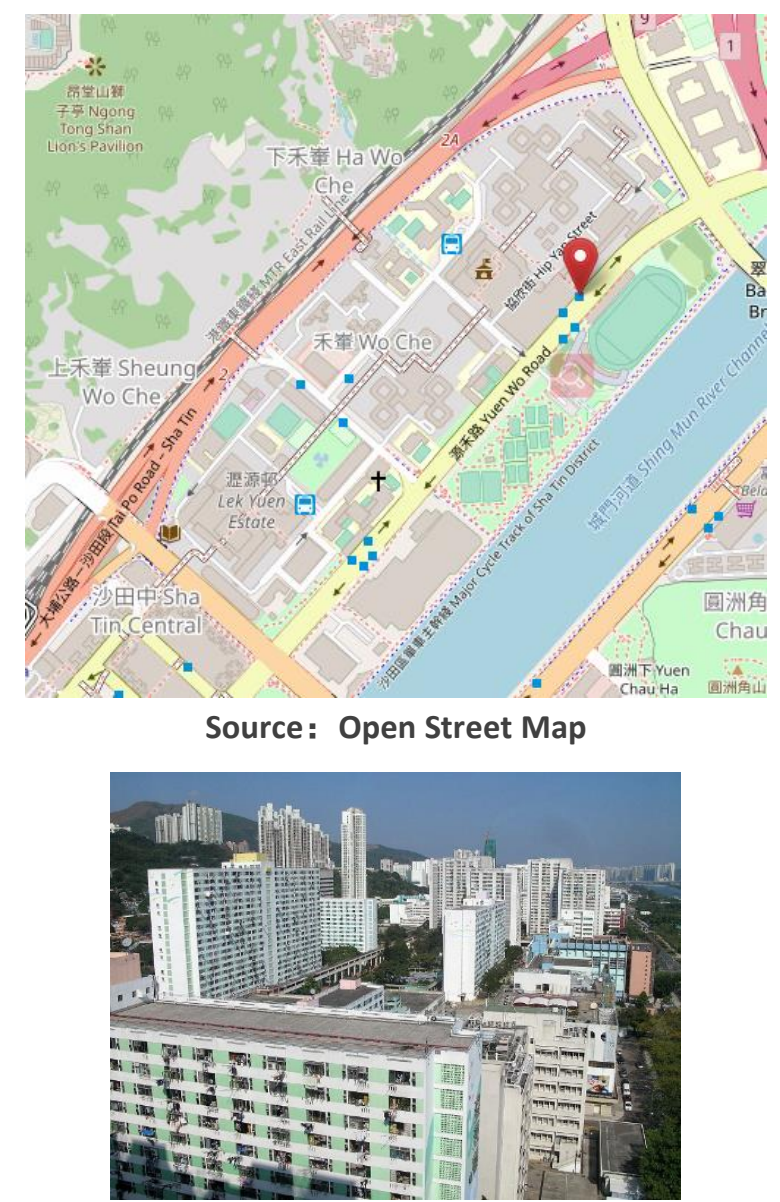

Source: https://zh.wikipedia.org/wiki/\%E7\%A6\%BE\%E8\%BC\%8B\%E9\%82\%A8

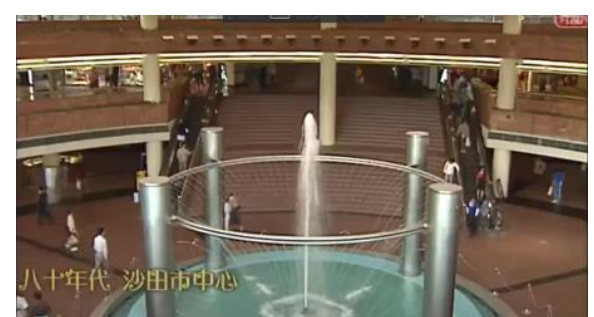

Source: https://www.youtube.com/watch?v=8xilYOFGmUE

After the second world war, millions of refugees rushed in Hong Kong. They make their living in low-labor industries. This laid the foundation for light industry and accumulated social wealth in Hong Kong. What's more, a series of social movement in 1960s force the colonial government to reflect the policy. Therefore, MacLehose's Home Ownership Scheme came out in 1970. It is a kind of social welfare planning in Hong Kong, also affected by the welfare policy in Britain. Tan Zheng believed that Sha New Town adopted the typical form of Cumbernauld. The Hong Kong British government emphasized the social housing function in new towns, ensuring the residents to work and to live in new towns. Such policies and urban planning compensated the workers and their families by reducing the cost of housing, but encouraged them did more consumption. Later in 1990s, the welfare space changed to consumption space. That means the younger generation, growing up in Uk Chuen (superblock) the welfare space In New Town, the ratio of public housing to private property developed by Hong Kong's property developers is usually 6:4. The public housing population accounts for $60 \%$ of the total population. 


\subsection{Comparison on service ability}

\begin{tabular}{|c|c|c|}
\hline & Sha Tin New Town & The southern of Brasilia \\
\hline Current population & 450,000 & 30,000 \\
\hline Planned population & 750,000 & $\begin{array}{c}\text { (the total for northern } \\
\text { and southern }) 557,000\end{array}$ \\
\hline Blocks & 21 & 124 \\
\hline $\begin{array}{c}\text { Number of buildings in a } \\
\text { single superblock }\end{array}$ & $7-10$ & $8-11$ \\
\hline Housing unit & 59,000 & $22320\left(124^{*} 360 / 2\right)$ \\
\hline Urban greening rate & 982.79 ha $\left(21.8^{m^{2}}\right.$ per & 3000 ha $\left(100^{m^{2}}\right.$ per capita $)$ \\
\hline capita & 18 & 14 \\
\hline Primary School & 20 & 4 \\
\hline Shopping mall & 19 & 9 \\
\hline Hospital & 18 & 8 \\
\hline
\end{tabular}

Source: 1) Google Earth,

2) https://www.britannica.com/place/Brasilia

\section{3) https://www.info.gov.hk/gia/general/201512/11/P201512110398.htm}

From the statistics, we can see the individual space is bigger in Brasilia than Sha Tin. Sha Tin develops in a denser way. In other words, it's more like modern city in Sha Tin than in Brasilia. The green area index also dose better for Brasilia. When comparing the community service, the facilities in Sha Tin is much adequate, serving in a humanized style.

\subsection{Similarity and Difference}

\begin{tabular}{|c|c|c|}
\hline Similarity & Sha Tin New Town & The southern of Brasilia \\
\hline & Starting as tabula rasa \\
\hline & Superblock with enough community service \\
\hline & Linear development in urban form \\
\hline & Improvement of housing environment \\
\hline
\end{tabular}

chart 1.

\begin{tabular}{|c|c|c|}
\hline Difference & Sha Tin New Town & The southern of Brasilia \\
\hline working & $\begin{array}{l}\text { A part of working in industrial } \\
\text { buildings, a part of working in } \\
\text { apartment }\end{array}$ & $\begin{array}{l}\text { Mostly in government bureaus in } \\
\text { central axis }\end{array}$ \\
\hline commuting & $10-20$ minutes & $\begin{array}{l}\text { (on average) } 96 \text { minutes } \\
\text { Waiting in stations for } 28 \text { minutes } \\
\text { Single travel distance for } 15.1 \mathrm{~km}\end{array}$ \\
\hline Traffic tool & Trains & Autos \\
\hline $\begin{array}{c}\text { Living } \\
\text { facilities' } \\
\text { Name }\end{array}$ & $\begin{array}{l}\text { Buildings are named by Chinese } \\
\text { words with good willing }\end{array}$ & $\begin{array}{l}\text { Streets are named by direction } \\
\text { and number }\end{array}$ \\
\hline zoning & Part of mixed function & Strict zoning \\
\hline Residents & Low-income workers & Civil servants \\
\hline development & Growing and expanding & Relevantly fixed by plan \\
\hline Industry & $\begin{array}{l}\text { Near the density residential } \\
\text { area }\end{array}$ & Very little, outside the urban area \\
\hline
\end{tabular}

Chart 2.

In a short summary, as the planned new capital of Brazil, Brasilia embodied the aspirations of the 
Brazilian social elite for the industrialized world. So, it needed a lot of grand architecture to embody the country's new image. The large-scale urban design of the architects coincides with the ideals of the Brazilian social elites such as President Kubitschek. and the modern city theory was relatively frontier in that time. The combination of these factors leads to the emergence of Brasilia, a city that shows the brilliance of modernism. By contrast, Sha Tin in Hong Kong didn't response to too much political implications. It could be more flexible to serve the people as much as possible. The superblocks both provided good infrastructure. But Hong Kong's officials considered more in human's use and chose a suitable transportation mode for new town. The zoning aimed at machine better running in city system. But when we found slight mixing of functions could make modern city more caring about people, the living environment could be more comfortable. This was the lessons that Sha Tin learn from Brasilia.

\section{Conclusion}

Brasilia is a great attempt in the urban planning history, although Corbusier's theory of modern city was for regenerate the old city. Interpretation to modern city theory helped not only architects, urban planners but also many common people see the problems in rapid industrial world. Professionals sum up experience in failure and the advanced more humanity planning, like Sha Tin practice 10 year later, avoiding many problems. Urban planning is a process of constant renewal, rather than a simple construction. We look for the ideal city, but the ideal city is under certain assumptions. Brasilia, a city built from scratch, is probably a city for architects. But Sha Tin New Town is built for citizens.

The vast majority of people in essence is a social animal. Communication with others is a kind of instinct. No human space is like a cageling, Some urban planning is for the full order without a little bit messy space. Of course, we can't deny this planning theory in dealing with the urban land shortages in the highspeed development and solving traffic problem. But a modern city idea should split view for function zoning and factors humanizing.

\section{References}

\footnotetext{
${ }^{1}$ Violich, F., 1974. Brasilia, Plan and Reality: A Study of Planned and Spontaneous Urban Development. Hispanic American Historical Review, 54(2), pp.343-344.

2 Bertaud, A., 1969. The costs of utopia: Brasilia, Johannesburg, and Moscow. Paranoá : cadernos de arquitetura e urbanismo, (18), pp.Paranoá : cadernos de arquitetura e urbanismo, 1969-12-31 (18).

${ }^{3}$ Faria, J.R., Ogura, L.M. \& Sachsida, A., 2013. Crime in a planned city: The case of Brasília. Cities, 32, pp.80-87.
}

${ }^{4}$ Pereira, Rafael Henrique Moraes, and Tim Schwanen., 2015. Commute time in Brazil (1992-2009): differences between metropolitan areas, by income levels and gender. No. 192. Discussion Paper.

${ }^{5}$ Dowall, D.E. \& Monkkonen, P., 2007. Consequences of the "Plano Piloto": The Urban Development and Land Markets of Brasília. Urban studies (Edinburgh, Scotland), 44(10), pp.1871-1887.

${ }^{6}$ Lai, L.W.-chung, 1998. The Leasehold System as a Means of Planning by Contract: The Case of Hong Kong. Town planning review, 69(3), pp.249-275.

7 Hui, E.C.M. \& Lam, M.C.M., 2005. A study of commuting patterns of new town residents in Hong Kong. Habitat international, 29(3), pp.421-437.

\section{U isocarp}


${ }^{8}$ Phillips, D.R., Yeh, A.G.O. \& Kim, K.-G., 1987. New towns in East and South-east Asia : planning and development, Hong Kong ; New York: Oxford University Press. 